\title{
KEPATUHAN WAJIB PAJAK UKM BATIK PRING SEDAPUR DI KABUPATEN MAGETAN
}

\author{
Ika Farida Ulfah ${ }^{1}$, Rosyida Rahma Izzati $^{2)}$ \\ ${ }^{1}$ Fakultas Ekonomi, Universitas Muhammadiyah Ponorogo \\ ikafaridaulfa@gmail.com \\ ${ }^{2}$ Fakultas Ekonomi, Universitas Muhammadiyah Ponorogo \\ r.rosyidaa@gmail.com
}

\begin{abstract}
Abstrak
Penelitian ini bertujuan untuk mengetahui bagaimana tingkat kepatuhan pajak dan faktor penghambat kepatuhan pajak pelaku UKM Batik Pring Sedapur di desa Sidomukti Kabupaten Magetan. Metode analisis yang digunakan adalah deskripsi kuantitatif dimana dari hasil penelitian dapat dijelaskan bahwa tingkat kepatuhan pajak para pelaku UKM Batik Pring Sedapur masih rendah. Ketidakpatuhan para pelaku UKM dalam membayar pajak disebabkan oleh berbagai faktor diantaranya kurangnya pengetahuan dalam perhitungan pajak, kesulitan menghitung pajak dikarenakan pembukuan yang terlalu sederhana, kurangnya sosialisasi perpajakan dan ketidakpercayaan pelaku UKM terhadap sistem pemerintahan yang ada.
\end{abstract}

Kata Kunci: pajak usaha kecil, kepatuhan, laporan pajak

\section{PENDAHULUAN}

Mencapai masyarakat adil dan makmur merupakan salah satu tujuan pembangunan Nasional. Agar tujuan tersebut dapat terwujud, pemerintah telah melakukan berbagai upaya, salah satunya dengan menjadikan sektor pajak sebagai penopang dalam membiayai pembangunan nasional. Pajak merupakan salah satu penerimaan Negara yang mengalami peningkatan dari tahun ke tahun.

Penerimaan Negara terbesar berasal dari sektor perpajakan, penerimaan pajak dapat dipengaruhi oleh keadaan perekonomian suatu Negara, karena pertumbuhan perekonomian akan meningkatkan penghasilan masyarakat yang secara tidak langsung juga akan meningkatkan kemampuan finansial masyarakat untuk membayar pajak.

UMKM mempunyai peran yang cukup besar dalam perekonomian Negara. UMKM mempunyai kontribusi kurang lebih 57\% dari PDB. Berdasarkan 
Undang-Undang Nomor 20 Tahun 2008 tentang Usaha Mikro, Kecil dan Menengah adalah Usaha Mikro bersifat produktif milik perorangan atau badan usaha perorangan yang telah memenuhi kriteria Usaha Mikro seperti yang telah diatur dalam UUPPh. Usaha Kecil merupakan usaha ekonomi yang bersifat produktif yang berdiri sendiri, dilakukan baik oleh orang perorangan maupun badan usaha yang bukan bagian anak atau cabang perusahaan yang dimiliki, dikuasai, atau menjadi bagian baik langsung maupun tidak langsung dari usaha menengah atau usaha besar yang memenuhi kriteria Usaha Kecil. Usaha Menengah adalah usaha ekonomi yang bersifat produktif yang berdiri sendiri, yang dilakukan oleh orang perseorangan atau badan usaha yang bukan bagian anak atau cabang perusahaan yang dimiliki, dikuasai, atau menjadi bagian baik langsung maupun tidak langsung dengan Usaha Kecil atau usaha besar dengan jumlah kekayaan bersih atau hasil penjualan tahunan.

Agar dapat meningkatkan jumlah penerimaan pajak secara sukarela, maka Negara dalam hal ini pemerintah telah menerbitkan PP No 46 Tahun 2013. Peraturan ini memiliki tarif yang lebih kecil dibandingkan tarif sebelumnya yakni sebesar $1 \%$ yang dipotong dari pendapatan kotor. Peraturan ini diberlakukan baik untuk pajak pribadi maupun WP badan yang mempunyai pendapatan kotor kurang dari 4.800.000.000,00 yang dibatasi pada penghasilan usaha. Dengan pengenaan biaya yang rendah diharapkan dapat mendorong pelaku UMKM agar mematuhi pajak,

Jumlah UMKM mengalami peningkatan sebesar 2,41\% dari jumlah 56.534.592 unit menjadi 57.895.721 unit. Kenaikan jumlah UMKM di Indonesia seharusnya dapat menambah penerimaan pajak Negara, namun kenyataannya tidak demikian. Kontribusi UMKM dalam penerimaan pajak kurang dari $1 \%$ dari total penerimaan pajak (http://www.pajak.go.id).

Pajak memegang peranan penting dalam penerimaan dalam negeri, namun hal ini masih belum optimal mengingat masih banyak wajib pajak yang belum patuh. UMKM dinilai belum mematuhi kewajiban perpajakan. Ketidakpatuhan ini membuat tidak maksimalnya pendapatan pajak di Indonesia. Penelitian 
terdahulu yang dilakukan oleh Klaudia (2017) juga menyatakan bahwa masih rendahnya kepatuhan wajib pajak pemilik UMKM.

Masalah kepatuhan pajak menjadi masalah yang penting bagi berbagai Negara, karena jika tidak ada kepatuhan dari wajib pajak maka akan memungkinkan munculnya tindakan penghindaran, pelalaian dan pengelakan pajak. Menurut Simanjuntak dan Mukhlis (2012:12) pajak merupakan transfer sumber dari sektor privat kesektor publik dimana pihak yang dikenakan pajak tidak dapat menerima manfaat pembayaran pajak secara langsung. Pajak ditujukan untuk mewujudkan tujuan ekonomi dan sosial bangsa. Jadi dapat disimpulkan bahwa pajak adalah penyerahan sebagian harta yang dimiliki rakyat kepada Negara yang diwajibkan oleh Negara dan berasaskan UndangUndang yang digunakan untuk belanja Negara

Kepatuhan terhadap peraturan perpajakan telah diatur dalam Undang Undang nomor 28 Tahun 2007. Peraturan tersebut ditujukan untuk wajib pajak baik wajib pajak badan maupun wajib pajak orang pribadi dengan tujuan agar para wajib pajak tersebut patuh dan senantiasa menaati serta menjalankan kewajibannya sebagai wajib pajak. Nurmatu, Dalam Rahayu (2009:138) kepatuhan perpajakan adalah keadaan dimana wajib pajak melakukan semua kewajiban dan hak perpajakannya. Kepatuhan yang dimaksud didalam kepatuhan pajak menggambarkan perilaku yang ada pada wajib pajak yang berkenan tunduk dan patuh dalam menjalankan kewajibannya sebagai wajib pajak, sesuai dengan aturan perundang-undangan yang berlaku.

Dalam suatu Negara jika penerimaan pajaknya tinggi maka dapat dipastikan bahwa tingkat kepatuhan wajib pajak terhadap perpajakan juga tinggi, hal ini terjadi karena kepatuhan wajib pajak merupakan salah satu faktor penting untuk merealisasikan target penerimaan pajak. Berdasarkan peraturan Menteri Keuangan Republik Indonesia Nomor 74/PMK.03/2012 disebutkan bahwa wajib pajak dapat dikatakan patuh apabila memenuhi persyaratan sebagai berikut: 
1. Adanya ketepatan waktu dalam menyampaikan Surat Pemberitahuan

2. Tidak memiliki tunggakan pajak pada semua jenis pajak, terkecuali tunggakan pajak tersebut telah memperoleh izin untuk mengangsur atau menunda pajak

3. Laporan keuangan yang ada diaudit oleh Akuntan Publik atau lembaga pengawasan keuangan pemerintah dengan pendapat Wajar Tanpa Pengecualian selama 3 (tiga) tahun berturut-turut

4. Tidak pernah terlibat tindak pidana di bidang perpajakan berdasarkan putusan pengadilan yang telah mempunyai kekuatan hukum tetap dalam jangka waktu 5 (lima) tahun terakhir.

Dalam beberapa Negara maju yang juga memberlakukan pajak, para warga Negara mendapatkan imbalan dari pembayaran pajaknya, berupa tunjangan dari Negara, misalkan tunjangan kesehatan, pendidikan dan transportasi gratis. Keuntungan ini secara langsung mapun tidak langsung dapata memberikan dorongan bagi wajib pajak untuk patuh dalam membayar pajak. Secara otomatis keinginan untuk mengingkari kewajiban membayar pajak akan terkikis.

\section{METODE PENELITIAN}

Jenis penelitian ini adalah penelitian deskriktif kuantitatif mengenai bagaimana kepatuhan wajib pajak UMKM Batik Pring Sedapur di kabupaten Magetan.

Metode pengumpulan data yang digunakan di penelitian ini yaitu natural setting, sumber data merupakan data primer, dan teknik pengumpulan data yang digunakan adalah wawancara mendalam, dokumentasi dan observasi partisipatif. Menurut sugiyono (2010: 310) pengumpulan data dengan observasi partisipatif peneliti terlibat dengan kegiatan harian orang yang sedang diamati sehingga data yang didapatkan menjadi lebih lengkap, tajam dan dapat mengetahui pada tingkatan makna dari setiap perilaku yang tampak Wawancara adalah pertemuan yang terjadi pada dua orang untuk bertukar informasi atau ide. Dokumen merupakan catatan peristiwa yang sudah berlalu, 
yang bisa berbentuk tulisan, gambar, atau karya-karya monumental lainnya dari seseorang.

Analisis yang digunakan dalam penelitian ini menggunakan analisis deskriptif dimana penulis melakukan wawancara mendalam kepada para pelaku UKM dan kemudian menganalisis hasil wawancara untuk mengetahui bagaimana Kepatuhan pajak UKM.

\section{HASIL PENELITIAN DAN PEMBAHASAN}

\section{Deskriptif objek penelitian}

Asal mula Batik tulis motif "Pring Sedapur" berasal dari desa Sidomukti dukuh Papringan, maka dari itu di desa Sidomukti banyak berdiri usaha kecil batik tulis yang bermotif pring sedapur. Adapun deskriftif dari setiap usaha tersebut adalah sebagai berikut:

1. UKM Batik KUBE Mukti Rahayu

KUBE Mukti Rahayu merupakan kelompok usaha bersama yang berdiri sejak tahun 2002. Anggota KUBE terdiri dari para ibu rumah tangga, baik muda maupun tua yang masih produktif yang dipimpin oleh ibu Siswati. Awalnya anggota kelompok terdiri dari 10 orang dan kini anggota kelompok sudah mencapai 34 orang. KUBE Mukti Rahayu berlokasi di Dusun Papringan Desa Sidomukti Kecamatan Plaosan Kabupaten Magetan. Lokasi ini berada di pedesaan, walaupun begitu lokasi ini cukup terkenal bagi warga/ calon pembeli. Akses menuju lokasi ini juga mudah dicapai. Dalam pendirian KUBE ini mendapat dukungan dari pemerintah berupa pelatihan keterampilan membatik dan juga berupa peralatan membatik. Anggota KUBE tidak mengeluarkan modal sama sekali. Dalam proses berdirinya dulu anggota tidak mendapat upah atas pekerjaannya. Mulai mendapat upah pada tahun 2004.

Seiring dengan berkembangnya usaha bersama ini, KUBE Mukti Rahayu telah memiliki lebih dari 25 motif, dan kini motif-motif tersebut sedang dalam proses pengurusan hak cipta. Motif batik ini terkenal dengan nama motif batik pring sedapur. Dimana motif batik di dominasi dengan 
gambar pring (dalam bahasa Indonesia: Bambu). Motif yang dihadirkan tidak monoton, terdapat kombinasi motif batik dengan gambar-gambar lain seperti hewan, bunga, batu, dan alam. Selain memproduksi batik tulis, KUBE Mukti Rahayu juga memproduksi batik cap atau sering di sebut dengan batik sony. Dimana produksi batik cap ini tidak dilakukan di KUBE Mukti Rahayu akan tetapi KUBE Mukti Rahayu menjalin kerjasama dengan pelaku usaha batik lainnya. Hasil kerja keras ibu-ibu ini pun tidak sia-sia. Terbukti pada tahun 2013 KUBE Mukti Rahayu memperoleh juara 2 tingkat provinsi dalam kegiatan lomba Kelompok Usaha Bersama.

\section{UKM Batik KUBE Mukti Lestari}

UKM Batik Mukti Lestari dibentuk oleh Kepala Desa, Bapak Tikno pada Maret 2006. UKM ini merupakan pengembangan dari UKM Batik Mukti Rahayu yang merupakan perintis awal UKM batik di Desa Sidomukti. UKM Batik Mukti Lestari yang berlokasi di Jl. Mukti Graha No. 03, Desa Sidomukti, tepatnya di Balai Desa Sidomukti, Plaosan, Magetan. Pada tahun 2009 UKM Batik Mukti Lestari melakukan restrukturisasi menjadi tiga KUBE (Kelompok Usaha Bersama). Meskipun dipecah menjadi tiga KUBE namun sistem baik pembelian bahan baku, produksi dan pemasaran tetap dalam satu UKM. Namun untuk pengelolaan keuangan dibagi pada masing masing KUBE.

3. UKM Batik Seruling Etan

UKM Batik Seruling Etan berdiri pada tahun 2014. Setelah bapak Sutikno tidak lagi menjabat sebagai kepala desa, beliau mendirikan sendiri usaha batik tulis yang bernama Seruling Etan di dusun Kalitengah desa Sidomukti kecamatan Plaosan. Tenaga kerja yang terlibat dalam pembuatan batik tersebut adalah ibu-ibu warga setempat sebanyak 20 orang. Mereka bekerja setiap hari dan sistem gaji secara harian serta kalau ada lemburan 
maka akan ditambah upah lembur. Mereka mengerjakan berdasarkan pesanan pelanggan. Batik yang dihasilkan dengan ciri has utama motif gambar pring atau dalam bahasa Indonesia disebut bambu. Pemasaran batik ini sudah sampai luar jawa, yaitu mulai daerah Magetan dan sekitarnya, Jakarta dan Kalimantan.

\section{Deskripsi Jawaban Responden}

\section{Pertanyaan : Berapa omset perbulan para pelaku UKM?}

Berdasarkan jawaban responden dapat diketahui bahwa 100\% para pelaku UKM omset per bulan sebesar Rp. 25.000.000- Rp.50.000.000. Menurut Undang-Undang No 20 Tahun 2008, omset yang dimiliki pelaku UKM menunjukkan usaha tersebut masih tergolong usaha kecil.

2. Pertanyaan: Apakah UKM mengetahui jika pajak merupakan salah satu sumber pendapatan Negara?

Tabel 1.

Pengetahuan tentang Pajak

\begin{tabular}{|c|c|c|}
\hline Pendapatan Negara & Ya & Tidak \\
\hline Presentase & $100 \%$ & $0 \%$ \\
\hline
\end{tabular}

Sumber: Pengolahan data penelitian, 2018

Dari data tersebut dapat diartikan bahwa semua UKM telah mengetahui pajak merupakan salah satu sumber pendapatan Negara. Menurut pelaku UKM pajak merupakan sumber penerimaan Negara yang paling besar yang digunakan untuk membiayai pengeluaran Negara. Tanpa pajak Negara akan mengalami kesulitan untuk membiayai semua kebutuhannya. Hal ini sejalan dengan teori Waluyo (2011:2) yang mengatakan bahwa salah satu fungsi dari pajak yaitu sebagai sumber pendapatan pada suatu Negara yang nantinya pendapatan tersebut akan digunakan untuk membiayai pengeluaran Negara. 
3. Pertanyaan: Apakah UKM telah menyadari bahwa membayar pajak adalah sebuah kewajiban?

Tabel 2.

Kesadaran Pajak

\begin{tabular}{|c|c|c|}
\hline Kesadaran Pajak & Ya & Tidak \\
\hline Presentase & $100 \%$ & $0 \%$ \\
\hline
\end{tabular}

Sumber: Pengolahan data penelitian, 2018

Dari data UKM yang di survey mengatakan bahwa semua UKM telah memiliki kesadaran tentang kewajibannya untuk membayar pajak. Namun kesadaran ini tidak diikuti dengan tindakan untuk membayar pajak.

4. Pertanyaan: Bagaimana kepercayaan UKM terhadap penggunaan uang hasil pemungutan pajak?

Tabel 3. Kepercayaan

\begin{tabular}{|c|c|c|}
\hline Kepercayaan & Percaya & Tidak Percaya \\
\hline Presentase & $33 \%$ & $67 \%$ \\
\hline
\end{tabular}

Sumber: Pengolahan data penelitian, 2018

Dari data UKM yang di survey mengatakan bahwa 33\% UKM telah mempercayai penggunaan uang pajak. Manurut pelaku UKM uang hasil pemungutuan pajak telah digunakan dengan baik, hal ini terbukti atas pembangunan infrastruktur yang telah dirasakan namun sebesar $67 \%$ pelaku UKM masih belum mempercayai penggunaan uang dari pemungutan pajak, mereka menganggap masih banyak kasus-kasus terkait penyelewengan uang hasil pemungutan pajak. 
5. Pertanyaan: Bagaimana kepuasan Pelaku UKM terhadap sosialisasi tentang perpajakan yang telah diberikan?

Tabel 4.

Sosialisasi Pajak

\begin{tabular}{|c|c|c|c|}
\hline $\begin{array}{c}\text { Kepuasan terhadap } \\
\text { Sosialisasi }\end{array}$ & Puas & Kurang Puas & Tidak Puas \\
\hline Presentase & $0 \%$ & $0 \%$ & $100 \%$ \\
\hline
\end{tabular}

Sumber: Pengolahan data penelitian, 2018

Dari data UKM yang di survey mengatakan bahwa semua UKM mengaku tidak puas terhadap sosialisasi yang diberikan karena memang belum pernah mendapatkan sosialisasi secara langsung sehingga tidak begitu memahami mengenai perpajakan.

\section{Pertanyaan: Apakah UKM telah membayar pajak?}

Tabel 5.

\section{Membayar Pajak}

\begin{tabular}{|c|c|c|}
\hline Membayar Pajak & Ya & Tidak \\
\hline Presentase & $33 \%$ & $67 \%$ \\
\hline
\end{tabular}

Sumber: Pengolahan data penelitian, 2018

Dari data UKM yang di survey mengatakan bahwa hanya 33\% UKM yang membayar pajak, sedangkan $67 \%$ tidak membayar pajak. Hal ini menunjukkan masih rendahnya kesadaran UKM dalam membayar pajak.

\section{Pertanyaan: Apakah UKM telah memiliki NPWP?}

Tabel 6.

\section{Memiliki NPWP}

\begin{tabular}{|c|c|c|}
\hline Memiliki NPWP & Ya & Tidak \\
\hline Presentase & $33 \%$ & $67 \%$ \\
\hline
\end{tabular}

Sumber: Pengolahan data penelitian, 2018 
Dari data UKM yang di survey, 33\% telah melaksanakan kewajibannya untuk memiliki Nomor Pokok Wajib Pajak (NPWP) sedangkan 67\% UKM belum memiliki NPWP.

\section{Pertanyaan: Apakah UKM telah melakukan pembukuan?}

Tabel 7.

\section{Melakukan Pembukuan}

\begin{tabular}{|c|c|c|}
\hline Melakukan pembukuan & Ya & Tidak \\
\hline Presentase & $100 \%$ & $0 \%$ \\
\hline
\end{tabular}

Sumber: Pengolahan data penelitian, 2018

Dari data yang diolah seluruh UKM telah melakukan pembukuan keuangan untuk usaha yang dijalankan, namun pembukuan yang dilakukan merupakan pembukuan sederhana, karena tidak memiliki tenaga ahli yang mampu untuk membuat pembukuan sesuai standar yang berlaku.

\section{Pertanyaan: Apakah UKM telah melakukan perhitungan pajak?}

Tabel 8.

\section{Menghitung Pajak}

\begin{tabular}{|c|c|c|}
\hline Menghitung Pajak & Ya & Tidak \\
\hline Presentase & $0 \%$ & $100 \%$ \\
\hline
\end{tabular}

Sumber: Pengolahan data penelitian, 2018

Dari data yang diolah seluruh UKM tidak menghitung pajak dikarenakan tidak memiliki keahlian untuk melakukan perhitungan dan kurangnya lengkapnya informasi keuangan yang dimiliki karena pembukuan yang masih sederhana. 


\section{Pertanyaan: Apakah UKM telah melaporkan SPT?}

Tabel 9. Melaporkan SPT

\begin{tabular}{|c|c|c|}
\hline Melaporkan SPT & Ya & Tidak \\
\hline Presentase & $0 \%$ & $100 \%$ \\
\hline
\end{tabular}

Sumber: Pengolahan data penelitian, 2018

Dari data yang diolah seluruh UKM tidak melaporkan SPT. Pelaku UKM mengaku mengalami kesulitan dalam mengisi laporan SPT. Mereka menganggap formulir laporan SPT yang harus diisi membingungkan dan merepotkan.

Berdasarkan hasil analisis dapat dijelaskan bahwa ketiga pelaku UKM tersebut masih tergolong usaha kecil yang memiliki rentang kekayaan bersih lebih darilima puluh juta rupiah sampai dengan paling banyak lima ratus juta rupiah. Kekayaan tersebut tidak termasuk tanah dan bangunan yang dijadikan tempat usaha. Hal ini sesuai dengan Undang-Undang No 20 Tahun 2008, yang menyatakan bahwa omset yang dimiliki pelaku UKM yang berkisar diantara itu menunjukkan usaha tersebut masih tergolong usaha kecil.

Pelaku UKM telah mengetahui bahwa pajak merupakan salah satu sumber pendapatan negara, yang nantinya akan berfungsi untuk membiayai pengeluaran-pengeluaran negara. Pelaku UKM juga telah menyadari kewajibannya untuk membayar pajak. Tapi pada praktiknya, hanya sebagian kecil pelaku UKM yang terdaftar sebagai wajib pajak sedangkan untuk UKM yang lainnya belum terdaftar sebagai wajib pajak. Untuk pembukuan keuangan semua UKM yang diteliti telah melakukan pembukuan, hanya saja pembukuan yang dilakukan masih bersifat sederhana sehingga menyulitkan pelaku UKM untuk melakukan perhitungan pajak dan melaporkan SPT.

Dari seluruh UKM yang diteliti tidak ada satupun UKM yang melakukan perhitungan pajak dan melaporkan SPT. Kurangnya pengetahuan terhadap perhitungan pajak menjadi salah satu kendala yang menyebabkan tidak dilakukannya perhitungan pajak dan pelaporan. Para pelaku UKM mengaku 
tidak memiliki kemampuan untuk melakukan perhitungan dan juga tidak memiliki tenaga pekerja dibidang itu, sehingga perhitungan dan pelaporan pajak tidak dilakukan. Padahal, pembukuan secara andal juga diperlukan untuk dapat memenuhi ketentuan perpajakan yang berlaku. Karena semakin baik dan berkualitas pembukuan yang dilakukan seorang wajib pajak, maka semakin lancar proses perhitungan pajak nya.

Selain itu kurang nya sosialisasi dari petugas pajak juga menjadi kendala. Pelaku UKM mengaku tidak mendapatkan sosialisasi terkait pajak UMKM. Padahal sosialisasi merupakan hal yang penting bagi pelaku UKM yang belum bisa untuk memahami pajak. Dengan adanya sosialisasi diharapkan dapat memberikan suatu pemahaman terhadap perpajakan dan mampu meningkatkan kesadaran pelaku UKM untuk patuh terhadap pajak.

Pelaku UKM juga menganggap proses pengurusan yang terlalu rumit sehingga enggan untuk mengurus pembayaran pajak dan pengurusan lainnya terkait perpajakan. Selain itu adanya ketidakpercayaan terhadap penggunaan uang pajak. Kasus korupsi yang terjadi di Indonesia sangat berpengaruh pada tingkat kepercayaan masyarakat terhadap pemerintah. Tingkat kepercayaan masyarakat pada sistem pemerintahan dan hukum yang berlaku di Indonesia turut serta mendorong perilaku wajib pajak untuk membayar pajaknya, jika masyarakat tidak percaya kepada pemerintah maka tingkat kepatuhan masyarakat untuk membayar pajak akan rendah.

\section{SIMPULAN}

Berdasarkan pembahasan diatas dapat diambil kesimpulan sebagai berikut:

1. Para pelaku UKM sebenarnya sudah mengetahui pentingnya pajak sebagai sumber pendapatan negara dan pelaku UKM juga telah menyadari akan kewajibannya untuk membayar pajak, namun hal ini tidak diikuti dengan kepatuhan dalam membayar pajak, terbukti dari belum adanya pelaku UKM yang menghitung, melaporkan dan membayar pajaknya.

2. Ketidakpatuhan para pelaku UKM dalam membayar pajak disebabkan oleh berbagai faktor diantaranya kurangnya pengetahuan dalam 
perhitungan pajak, kesulitan menghitung pajak dikarenakan pembukuan yang terlalu sederhana, kurangnya sosialisasi perpajakan dan ketidakpercayaan pelaku UKM terhadap sistem pemerintahan yang ada.

\section{Saran}

Berdasarkan hasil pembahasan, maka saran dari peneliti adalah sebagai berikut:

1. Pelaku UKM sebaiknya membuat pembukuan yang terstruktur terhadap hasil usahanya untuk mempermudah dalam melakukan perhitungan dan pelaporan pajak.

2. Perlu adanya peningkatan SDM terutama dibagian keuangan dengan mengikuti berbagai pelatihan agar dapat melakukan perhitungan pajak dengan baik danbenar.

3. Perlunya sosialisasi dari petugas pajak terkait peraturan perpajakan UMKM agar dapat meningkatkan kepatuhan pajak para pelaku UKM.

\section{REFERENSI}

Gunadi. 2002. Indonesian Taxation: A Reference Guide. Jakarta: Multi Utama Publishing.

Rahayu, Siti Kurnia. 2009. Perpajakan Indonesia Konsep \& Aspek Formal. Yogyakarta : Graha Ilmu.

Rakhmad, Basuki. 2015. Merawat Potensi Pajak Sektor UMKM Melalui Kehumasan. www.pajak.go.id.

Robbins, Stephen P. 2006. Perilaku Organisasi Edisi kesepuluh. Jakarta: PT. Indeks Kelompok Gramedia.

Simanjuntak, Timbul H \& Imam M. 2012. Dimensi Ekonomi Perpajakan dalam Pembangunan Ekonomi. Jakarta: Raih Asah Sukses.

Sugiyono. 2010. Metode Penelitian Bisnis. Bandung: Alfabeta.

Sura Klaudia, Dewi Rimba Riwayanti \& Aminatunnisa. 2017. Menggali Realitas Kepatuhan Wajib Pajak Pemilik UMKM. Jurnal PETA Vol. 2 No. 1. 
Waluyo. 2011. Perpajakan Indonesia Edisi 10 Buku 1. Jakarta: Salemba Empat. 